\title{
Vascular Dysfunction Induced by Elevated Glucose Levels in Rats Is Mediated by Vascular Endothelial Growth Factor
}

\author{
Ronald G. Tilton, ${ }^{\star}$ Takahiko Kawamura," Katherine C. Chang,,$"$ Yasuo Ido, ${ }^{\|}$Robert J. Bjercke, ${ }^{\S}$ Clifford C. Stephan, ${ }^{\ddagger}$ \\ Tommy A. Brock, ${ }^{\ddagger}$ and Joseph R. Williamson" \\ $*$ Department of Cell Biology, ${ }^{\ddagger}$ Department of Pharmacology, and ${ }^{\S}$ Department of Immunology, Texas Biotechnology Corporation, \\ Houston, Texas 77030; "Department of Pathology, Washington University School of Medicine, St. Louis, Missouri 63110; and \\ "Department of Internal Medicine, Chubu Rosai Hospital, Nagoya 455, Japan
}

\begin{abstract}
The purpose of these experiments was to investigate a potential role for vascular endothelial growth factor (VEGF) in mediating vascular dysfunction induced by increased glucose flux via the sorbitol pathway. Skin chambers were mounted on the backs of Sprague-Dawley rats and $1 \mathrm{wk}$ later, granulation tissue in the chamber was exposed twice daily for $7 \mathrm{~d}$ to $5 \mathrm{mM}$ glucose, $30 \mathrm{mM}$ glucose, or $1 \mathrm{mM}$ sorbitol in the presence and absence of neutralizing VEGF antibodies. Albumin permeation and blood flow were increased two- to three-fold by $30 \mathrm{mM}$ glucose and $1 \mathrm{mM}$ sorbitol; these increases were prevented by coadministration of neutralizing VEGF antibodies. Blood flow and albumin permeation were increased $\sim 2.5$-fold $1 \mathrm{~h}$ after topical application of recombinant human VEGF and these effects were prevented by nitric oxide synthase (NOS) inhibitors (aminoguanidine and $N^{\mathrm{G}}$-monomethyl L-arginine). Topical application of a superoxide generating system increased albumin permeation and blood flow and these changes were markedly attenuated by VEGF antibody and NOS inhibitors. Application of sodium nitroprusside for $7 \mathrm{~d}$ or the single application of a calcium ionophore, A23187, mimicked effects of glucose, sorbitol, and VEGF on vascular dysfunction and the ionophore effect was prevented by coadministration of aminoguanidine. These observations suggest a potentially important role for VEGF in mediating vascular dysfunction induced by "hypoxia-like" cytosolic metabolic imbalances (reductive stress, increased superoxide, and nitric oxide production) linked to increased flux of glucose via the sorbitol pathway. (J. Clin. Invest. 1997. 99:2192-2202.) Key words: polyol pathway • vascular endothelial growth factor $\bullet$ nitric oxide $\bullet$ blood flow $\bullet$ albumin permeation
\end{abstract}

\section{Introduction}

A large body of evidence indicates that multiple metabolic imbalances associated with elevated tissue glucose levels contribute to the pathogenesis of diabetic vascular complications (re-

Address correspondence to Ronald G. Tilton, Department of Cell Biology, Texas Biotechnology Corp., 7000 Fannin, Houston, TX 77030. Phone: 713-796-8822 ext. 112; FAX: 713-796-8232; E-mail: rtilton@ tbc.com

Received for publication 4 November 1996 and accepted in revised form 12 February 1997.

J. Clin. Invest.

(C) The American Society for Clinical Investigation, Inc.

0021-9738/97/05/2192/11 \$2.00

Volume 99, Number 9, May 1997, 2192-2202 viewed in 1-5). Many of these metabolic perturbations have been linked to increased flux of glucose via the sorbitol pathway, a two-step enzymatic process in which D-glucose is reduced to sorbitol (coupled to oxidation of NADPH to $\mathrm{NADP}^{+}$) by aldose reductase followed by the subsequent oxidation of sorbitol to fructose (coupled to reduction of $\mathrm{NAD}^{+}$to NADH) by sorbitol dehydrogenase. Studies utilizing inhibitors of these two enzymes indicate that increased glucose metabolism via this pathway is causally linked to vascular dysfunction (increased blood flow and vascular hyperpermeability) in diabetic animals (6-8), and to increased blood flow in nondiabetic animals with acute hyperglycemia induced by intravenous glucose infusion (9). Furthermore, elevation of tissue sorbitol levels at physiological glucose concentration mimics effects of elevated glucose on vascular dysfunction (10), and vascular changes induced by increased glucose or sorbitol levels are prevented by raising tissue pyruvate levels (which drives oxidation of $\mathrm{NADH}$ to $\mathrm{NAD}^{+}$coupled to reduction of pyruvate to lactate by lactate dehydrogenase) $(10,11)$. These findings support the hypothesis that sorbitol pathway-linked vascular dysfunction is mediated largely by an increased cytosolic ratio of free $\mathrm{NADH} / \mathrm{NAD}^{+}$coupled to the oxidation of sorbitol to fructose, which results in a "hypoxia-like" cytosolic reductive stress $(8,12)$.

This same redox imbalance develops in hypoxic and ischemic tissues (in mitochondria as well as in the cytoplasm) due to impaired oxidation of NADH to $\mathrm{NAD}^{+}$by the mitochondrial electron transport chain and also is associated with vasodilation, increased blood flow, and vascular hyperpermeability. The finding that pyruvate attenuates vascular dysfunction induced by hypoxia and ischemia $(13,14)$, by acute hyperglycemia in nondiabetic rats, and by diabetes, suggests that an increased cytosolic ratio of $\mathrm{NADH} / \mathrm{NAD}^{+}$may play an important role in mediating vascular dysfunction in all three conditions.

Vascular endothelial growth factor/vascular permeability factor (VEGF) $)^{1}$ is an endothelial cell-specific mitogen (15), but also displays other biologically relevant activities, such as the ability to increase blood vessel permeability (16) and to induce vascular relaxation (17). It is well documented that hypoxia, both in vitro and in vivo, is a potent inducer of VEGF (18-20), which is one potential mediator of the increases in blood flow and vascular hyperpermeability caused by hypoxia. In view of the similar effects of hypoxia and of elevated tissue glucose levels on cytosolic NADH/NAD ${ }^{+}$and on vascular dysfunction, the present experiments were performed to investigate whether VEGF mediates vascular dysfunction induced by

1. Abbreviations used in this paper: AG, aminoguanidine; L-NMMA, $N^{\mathrm{G}}$-monomethyl L-arginine; $\mathrm{L} / \mathrm{P}$, lactate/pyruvate ratio; $\mathrm{NO}$, nitric oxide; NOS, NO synthase; VEGF, vascular EGF/vascular permeability factor. 
elevated tissue glucose levels. We report herein that neutralizing VEGF antibodies prevent the increases in blood flow and vascular albumin permeation induced by accelerated sorbitol pathway activity as well as by increased superoxide levels generated by using hypoxanthine/xanthine oxidase. In addition, we demonstrate that blood flow increases and vascular hyperpermeability induced by elevated glucose levels and by superoxide can be mimicked by nitric oxide donors and by a calcium ionophore; the superoxide and calcium ionophore changes can be prevented by inhibitors of nitric oxide synthase (NOS). These data support the likelihood that VEGF plays an important role in mediating increased blood flow and vascular albumin permeation in tissue exposed to accelerated glucose flux via the sorbitol pathway, and that these VEGF effects are mediated via nitric oxide(NO)-dependent mechanisms.

\section{Methods}

\section{Animals and materials}

Male Sprague-Dawley rats ( $\sim 225$ grams $)$ were purchased from Sasco (Indianapolis, IN), female 8-wk-old BALB/c mice were purchased from Harlan Sprague Dawley, Inc. (Indianapolis, IN), and 10-wk-old New Zealand White rabbits were purchased from Myrtle's Rabbitry (Thompson Station, TN). Housing and anesthesia concurred with the guidelines established by the Institutional Animal Welfare Committee, in accordance with the Public Health Service Guide for the Care and Use of Laboratory Animals, United States Department of Agriculture regulations, and the American Veterinary Medicine Association's Panel on Euthanasia guidelines. Rats were housed individually and fed standard rat chow (rodent chow 5001; Ralston Purina, Richmond, IN) and water ad libitum. Rabbits were housed individually and fed 5 oz rabbit chow/day (rabbit chow 7015; Harlan Teklad, Madison, WI) and water ad libitum. All animals were on a 12-h light/dark cycle. The aldose reductase inhibitor, tolrestat, was provided by Wyeth Ayerst (Princeton, NJ) and the sorbitol dehydrogenase inhibitor, CP166,572, was provided by Pfizer (Groton, CT). ${ }^{125} \mathrm{I},{ }^{131} \mathrm{I}$, and ${ }^{46} \mathrm{Sc}$-labeled microspheres were obtained from NEN Research Products (Boston, MA). All other chemicals and reagents, including aminoguanidine (hemisulfate), $N^{\mathrm{G}}$-monomethyl L-arginine (L-NMMA), A23187, sodium nitroprusside (SNP), hypoxanthine, xanthine oxidase (grade III), superoxide dismutase, Complete and Incomplete Freund's adjuvants, and a nonspecific rabbit immunoglobulin were obtained from Sigma Chemical Co. (St. Louis, MO).

\section{Recombinant human VEGF and neutralizing $V E G F$ antibodies}

Recombinant human VEGF. The full-length coding region for the 165 amino acid isoform of VEGF ( $\mathrm{rhVEFF}_{165}$ ) was obtained from human A431 epidermal carcinoma cells by the PCR with the following oligos: sense, 5'-CCGAAACCATGAACTTTCTGC-3' and antisense, 5'-TCCTTCCTCCTGCCCGGCTCA-3'. PCR products were subcloned into the TA-vector (Invitrogen Corp., San Diego, CA). Clones containing rhVEGF 165 were gel purified and isolated from the TA-vector as a Xho1-BamH1 fragment and then ligated into the Xho1/BamH1 site of the pBacPAK8 vector (Clontech; Palo Alto, CA). Transfection into Sf 21 cells and the screening for recombinant viruses were performed as described by the manufacturer (Clontech).

Sf 21 cells $(50,000$ cells in 10-ml of serum-free medium, Sf 900 II SFM from Gibco BRL, Gaithersburg, MD) were infected with recombinant virus in suspension for $3 \mathrm{~h}$ at $27^{\circ} \mathrm{C}$. Cells were then plated into $175-\mathrm{cm}^{2}$ flasks (Falcon, Franklin Lakes, NJ) in a total volume of $25 \mathrm{ml}$ of serum-free medium. After $3 \mathrm{~d}$ at $27^{\circ} \mathrm{C}$, conditioned medium was collected, cellular debris removed by centrifugation $(3,000 \mathrm{rpm}$ for $5 \mathrm{~min}$ at $4^{\circ} \mathrm{C}$ ), then stored at $4^{\circ} \mathrm{C}$ until purification. The rhVEGF $_{165}$ was partially purified with Hi-Trap heparin-sepharose columns (Pharmacia Biotech Inc., Alameda, CA) using methods described by Fiebich et al. (21). Partially purified rhVEGF $_{165}$ was quantified by ELISA (R\&D Systems; Minneapolis, MN) and by competition binding with [ ${ }^{125}$ I]VEGF (Biomedical Technologies Inc., Stoughton, MA) to human umbilical vein endothelial cells.

Neutralizing polyclonal VEGF antibody. The peptide used for antibody preparation was the $\mathrm{NH}_{2}$ terminal 24 amino acid portion of rhVEGF which was synthesized (Symphony; Rainin, Woburn, MA), purified with HPLC, then coupled to keyhole limpet hemocyanin (Imject Activated KLH; Pierce, Rockford, IL) via the maleimideactivated carrier protein which crosslinks cysteine to KLH. Polyclonal rabbit antisera was raised in 10-wk-old New Zealand White rabbits immunized three times at 6 -wk intervals by intradermal injection of $200 \mu \mathrm{g}$ of the KLH-linked peptide. Antisera titer was tested for reactivity to rhVEGF by standard ELISA methods as described previously (22), with the exception that alkaline phosphatase conjugated mouse anti-rabbit gamma IgG together with $p$-nitrophenyl phosphate substrate system (Kirkegaard \& Perry Laboratories Inc., Gaithersburg, MD) was used for the ELISA. Neutralizing antibody activity was tested by inhibition of ${ }^{125}$ I-VEGF binding to recombinant human Flt-1 coated onto microtitre wells (see below). Purified IgG was prepared by Protein A chromatography.

Neutralizing monoclonal VEGF antibody. Five female 8-wk-old $\mathrm{BALB} / \mathrm{c}$ mice were immunized, then boosted three times, $21 \mathrm{~d}$ apart, by intraperitoneal and subcutaneous injections of $50 \mu \mathrm{g}$ of rhVEGF, which was emulsified with an equal volume of CFA for the primary immunization and Incomplete Freund's adjuvant for secondary immunizations. All five mice produced high serum titres to rhVEGF as measured by the ELISA assay described above, except that the second antibody was alkaline phosphatase conjugated goat anti-mouse $\gamma$ IgG. The mouse with the highest serum level of anti-rhVEGF and neutralizing antibody activity was injected intravenously with an additional $30 \mu \mathrm{g}$ of immunogen in PBS, $21 \mathrm{~d}$ after the last immunization. $3 \mathrm{~d}$ later, spleen cells of the mouse were harvested for production of hybridomas to human recombinant VEGF using previously described techniques $(22,23)$.

Two hybridoma cell lines with highest antibody titre and neutralizing antibody activity were cloned three to four times by limiting dilution in 96-well microtiter plates. Ascites fluid was collected from pristane primed $\mathrm{BALB} / \mathrm{c}$ mice injected intraperitoneally with each of the cloned hybridomas $\left(10^{7}\right.$ cells $)$ and purified $\operatorname{IgG}$ was prepared by Protein A chromatography. The isotype and light chain composition of monoclonal antibodies were determined using ELISA, substituting secondary antibody reagents with alkaline phosphatase conjugated rabbit IgG antibodies specific for mouse IgG1, IgG2a, IgG2b, IgG3, IgM, or mouse kappa or lambda light chains.

Characterization of VEGF antibodies. Binding studies were performed using a fusion protein composed of the seven loop ectodomain of Flt- 1 fused to the heavy chains of a mouse $\operatorname{IgG}_{2 \mathrm{a}}$ antibody. The fusion protein was captured onto Immulon 4 strip wells with $\mathrm{IgG}_{2 \mathrm{a}}$-specific goat anti-mouse antibody. Increasing concentrations of polyclonal and monoclonal anti-VEGF antibody were incubated separately with $4 \mathrm{ng} / \mathrm{ml}{ }^{125} \mathrm{I}-\mathrm{VEGF}$ (Biomedical Technologies Inc., Stoughton, MA) for $30 \mathrm{~min}$ at $37^{\circ} \mathrm{C}$ before adding to the receptor. Nonspecific binding was defined as the binding measured in the presence of a 100-fold molar excess of unlabeled VEGF. Incubations were terminated after $60 \mathrm{~min}$ at $22^{\circ} \mathrm{C}$ by washing the wells once with $400 \mu \mathrm{l}$ of ice-cold PBS, then twice more with $200 \mu \mathrm{l}$ of ice-cold PBS. Bound VEGF was measured in a Life Technology Inc. $\gamma$ counter (Schaumburg, IL).

$\mathrm{A} \mathrm{Ca}^{2+}$-sensitive fluorescent dye, Fura-2 (Molecular Probes, Eugene, $\mathrm{OR}$ ), was used to monitor changes in intracellular $\mathrm{Ca}^{2+}$ levels in human endothelial cell suspensions as previously described (24). Cells were loaded with $2 \mu \mathrm{M}$ of the cell permeant acetoxymethylester derivative of Fura- 2 for $20 \mathrm{~min}$ at $37^{\circ} \mathrm{C}$. Antibodies $(5 \mu \mathrm{g} / \mathrm{ml} \mathrm{mono-}$ clonal and $90 \mu \mathrm{g} / \mathrm{ml}$ polyclonal final concentration) were incubated with rhVEGF $\left(10 \mathrm{ng} / \mathrm{ml}\right.$ final concentration) for $30 \mathrm{~min}$ at $37^{\circ} \mathrm{C}$ before addition to Fura-2-loaded cells $\left(5 \times 10^{5}\right.$ in $2 \mathrm{ml}$ PBS $)$. Fura-2 flu- 
orescence was monitored with a Photon Technologies International fluorometer (South Brunswick, NJ) at 340 and $380 \mathrm{~nm}$ and calibrated using digitonin $(0.25 \mathrm{mM})$ and EGTA $(10 \mathrm{mM}, \mathrm{pH} 12.0)$ to obtain maximum and minimum fluorescence signals, respectively. Intracellular $\mathrm{Ca}^{2+}$ concentrations were calculated using the formula: $\left[\mathrm{Ca}^{2+}\right]_{\mathrm{i}}=$ $K_{\mathrm{d}}\left(R-R_{\min }\right) /\left(R_{\max }-R\right) \times\left(\mathrm{EGTA}_{380} / \mathrm{DIG}_{380}\right)$ as previously described (25).

\section{Granulation tissue skin chamber}

A modification of the skin chamber model utilized by Lundberg and Gerdin (26) as described in previous studies $(9,11)$ was used for these studies. Rats were anesthetized with a rodent cocktail $(0.6 \mathrm{ml} / \mathrm{kg}$ body weight injected intraperitoneally) containing ketamine $(100 \mathrm{mg} / \mathrm{ml})$, xylazine $(20 \mathrm{mg} / \mathrm{ml})$, and acepromazine $(10 \mathrm{mg} / \mathrm{ml})$, hair was shaved from their backs, and 2-cm circles of skin were removed from the upper back on either side of the midline. The flanged base of the plastic chamber was then sutured to the skin at the wound margins with the skin overlapping the flange to prevent reepithelialization of the granulation tissue inside the chamber. Granulation tissue containing new vessels formed on the surface of the exposed fascia inside the chamber. The chambers were equipped with stainless steel screwcaps which permit repetitive addition of pharmacologic agents to the granulation tissue.

\section{Measurement of vascular albumin permeation and blood flow in granulation tissue}

Vascular albumin permeation (expressed as microgram plasma/gram tissue wet weight per min) was quantified using a double isotope-dilution technique based on the injection of ${ }^{125} \mathrm{I}$ - and ${ }^{131} \mathrm{I}$-BSA $(6,27) .{ }^{125} \mathrm{I}$ BSA was used to quantify vascular albumin permeation after $10 \mathrm{~min}$ of tracer circulation, while ${ }^{131} \mathrm{I}$-BSA served as a plasma volume marker to correct ${ }^{125}$ I-BSA tissue activity for tracer contained within vessels. Blood flow was assessed by injection of $11.3 \mu \mathrm{m}$ diameter ${ }^{46} \mathrm{Sc}$-microspheres.

Rats were anesthetized with Inactin (Byk Gulden, Konstanz, Germany) ( $\sim 100 \mathrm{mg} / \mathrm{kg}$ i.p. $)$, and core body temperature was maintained at $37 \pm 0.5^{\circ} \mathrm{C}$. The left femoral vein (for tracer injection), left iliac artery (connected to a $1-\mathrm{ml}$ syringe attached to a withdrawal pump [940; Harvard Apparatus, Inc., South Natick, MA] preset to withdraw at a constant rate of $0.055 \mathrm{ml} / \mathrm{min}$ ), right subclavian artery (for blood pressure monitoring), and right carotid artery were cannulated with polyethylene tubing ( $0.58 \mathrm{~mm}$ i.d.) filled with heparinized saline (400 U heparin $/ \mathrm{ml})$. The tip of the carotid artery cannula was placed in the left ventricle of the heart and was used for injection of radiolabeled microspheres. A tracheotomy was performed to facilitate respiration.

At time $0,{ }^{125}$ I-BSA $\left(20 \times 10^{6} \mathrm{cpm}\right.$ in $0.3 \mathrm{ml}$ of saline $)$ was injected i.v. and the withdrawal pump was started simultaneously. 8 min later, ${ }^{131}$ I-BSA $\left(20 \times 10^{6} \mathrm{cpm}\right.$ in $0.3 \mathrm{ml}$ of saline $)$ was injected and $1 \mathrm{~min}$ later, the ${ }^{46} \mathrm{Sc}$-microspheres $\left(2 \times 10^{6}\right.$ in $0.2 \mathrm{ml}$ saline containing $5 \%$ dialyzed ficoll) were injected slowly over $\sim 30 \mathrm{~s}$. At the 10 -min mark, the heart was excised to stop all blood flow, the withdrawal pump was stopped simultaneously, and the granulation tissue in both chambers was removed. The granulation tissue and arterial plasma sample were weighed, counted in a gamma spectrometer, and corrected for background. ${ }^{125}$ I-BSA activity in granulation tissue was corrected for tracer contained within the tissue vasculature by multiplying ${ }^{125} \mathrm{I}-\mathrm{BSA}$ activity in the tissue by the ratio of ${ }^{125} \mathrm{I}$-BSA $/{ }^{131}$ I-BSA activities in the arterial plasma sample obtained at the end of the experiment. The vascular-corrected $125 \mathrm{I}$-BSA activity was divided by the time-averaged ${ }^{125}$ I-BSA plasma activity (obtained from a well mixed sample of plasma taken from the withdrawal syringe) and by the tracer circulation time $(10 \mathrm{~min})$ and then normalized per gram of tissue wet weight. Blood flow was calculated as previously described (27) using conventional techniques; total activity of ${ }^{46} \mathrm{Sc}$ in the granulation tissue was divided by the activity of ${ }^{46} \mathrm{Sc}$ in the reference blood sample obtained from the withdrawal pump syringe, multiplied by the pump withdrawal rate, and expressed as milliliter/gram of tissue per min.

\section{Experimental protocols}

Some experiments were initiated $7 \mathrm{~d}$ after mounting skin chambers with twice daily treatments continuing for $7 \mathrm{~d}$. These included assessing effects of: (a) VEGF antibodies on glucose- and sorbitol-induced vascular changes; (b) SOD on glucose-induced changes; $(c)$ topical application of a nitric oxide donor, sodium nitroprusside. The latter two experiments were designed to explore roles for superoxide and nitric oxide in glucose-induced vascular dysfunction. $1.5 \mathrm{ml}$ of $25 \mathrm{mM}$ Hepes buffer ( $\mathrm{pH} 7.4,137 \mathrm{mM} \mathrm{NaCl}, 4.2 \mathrm{mM} \mathrm{KCl}, 3 \mathrm{mM} \mathrm{Na}_{2} \mathrm{HPO}_{4}$, $100 \mu \mathrm{g} / \mathrm{ml}$ penicillin $\mathrm{G}, 10 \mu \mathrm{g} / \mathrm{ml}$ gentamicin, $2 \%$ polyvinylpyrrolidone) plus individual reagents being tested for each experiment were added to individual chambers at 9:00 a.m. and 5:00 p.m. for 7 d. Within an hour of the final treatment on day 14, albumin clearance and blood flow were assessed as detailed above.

Additional experiments exploring links between superoxide, nitric oxide, and VEGF were initiated $11 \mathrm{~d}$ after mounting tissue chambers. In these experiments, $1.5 \mathrm{ml}$ of Hepes buffer containing $10 \mathrm{mM}$ hypoxanthine $+500 \mathrm{mU}$ xanthine oxidase $(\mathrm{XO}) \pm 1 \mathrm{mM}$ aminoguanidine (AG), $1 \mathrm{mM}$ L-NMMA, or $30 \mu \mathrm{g} / \mathrm{ml}$ VEGF mAb were added to individual chambers at 9:00 a.m. and 5:00 p.m. for $3 \mathrm{~d}$. Albumin clearance and blood flow were assessed on day 14 within an hour of the final treatment.

Acute experiments evaluating effects of single, topical applications of VEGF or the calcium ionophore, A23187, were initiated $14 \mathrm{~d}$ after mounting tissue chambers. Since a well characterized effect of VEGF interaction with its receptor is increased intracellular calcium, the latter experiment was performed to assess: (a) effects of these calcium changes on vascular dysfunction, and $(b)$ if these effects were mediated via NOS. $2 \mathrm{ml}$ of Hepes buffer containing 100 pM VEGF or $0.1 \mu \mathrm{M}$ A23187 were applied topically to the granulation tissue, and albumin clearance and blood flow were assessed $1 \mathrm{~h}$ later. In two separate experiments, $2 \mathrm{mM}$ L-NMMA or $1 \mathrm{mM}$ aminoguanidine were added to granulation tissue $2 \mathrm{~h}$ before, then coapplied with $100 \mathrm{pM}$ VEGF, and $1 \mathrm{mM}$ aminoguanidine was applied to granulation tissue $1 \mathrm{~h}$ before, and again with the A23187; in both experiments, albumin clearance and blood flow were assessed $1 \mathrm{~h}$ after adding VEGF or A23187. To control for effects of $2 \mathrm{mM} \mathrm{L-NMMA}$ and $1 \mathrm{mM}$ aminoguanidine on blood flow and vascular permeability in granulation tissue, chambers were separately treated with $5 \mathrm{mM}$ glucose plus the NOS inhibitors twice a day for $7 \mathrm{~d}$.

\section{Glucose-induced changes in granulation tissue lactate, pyruvate, and fructose}

Experimental protocols. To document sorbitol pathway-linked reductive stress in granulation tissue, in vitro experiments were performed on granulation tissue removed from chambers mounted on nondiabetic control rats and exposed to $5 \mathrm{mM}$ glucose daily for 7-10 d as described above. The tissue was quartered with a razor blade and preincubated in Krebs bicarbonate-Hepes buffer $(110 \mathrm{mM} \mathrm{NaCl}$, $4.5 \mathrm{mM} \mathrm{KCl}, 1 \mathrm{mM} \mathrm{CaCl}_{2}, 0.5 \mathrm{mM} \mathrm{MgCl}_{2}, 1.5 \mathrm{mM} \mathrm{Na}_{2} \mathrm{HPO}_{4}, 30 \mathrm{mM}$ Hepes, $15 \mathrm{mM} \mathrm{NaHCO}, 5 \mathrm{mM}$ glucose, and 0.5\% BSA), pH 7.4, gassed with $95 \%$ oxygen and $5 \% \mathrm{CO}_{2}$ for $20 \mathrm{~min}$ at $37^{\circ} \mathrm{C}$. Each tissue quarter was then transferred to $1 \mathrm{ml}$ fresh buffer containing 5 or 50 $\mathrm{mM}$ glucose $\pm 70 \mu \mathrm{M}$ tolrestat (an aldose reductase inhibitor; WyethAyerst), regassed, and incubated an additional $2 \mathrm{~h}$. At the termination of the incubation, granulation tissue was snap frozen in Wollenberger tongs chilled in liquid nitrogen and powdered in a percussion mill kept on dry ice, then extracted as detailed below.

In additional experiments, granulation tissue was removed from the backs of control, diabetic, and diabetic + tolrestat $(0.2 \mathrm{mmol} / \mathrm{kg}$ body weight per $\mathrm{d}$ rats mixed in the diet) $\sim 10 \mathrm{~d}$ after chamber implantation, snap frozen in liquid nitrogen, powdered in a percussion mill kept on dry ice, and extracted as detailed below. Diabetes was induced by intravenous administration of $55 \mathrm{mg} / \mathrm{kg}$ body weight streptozotocin (Sigma Chemical Co.) dissolved in PBS immediately before injection. Induction of diabetic state was confirmed by documenting elevated nonfasting morning plasma glucose levels $(>200 \mathrm{mg} / \mathrm{dl})$, increased 24 -h urine volumes ( $>10$-fold vs controls), and hyperphagia. 
Tissue chambers were mounted on rats with diabetes of $\sim 2$ wk duration.

Preparation of tissue extracts and analytical methods for measuring metabolites. Tissue extracts for measurement of metabolites were prepared by combining $\sim 200 \mathrm{mg}$ of tissue powder with $0.48 \mathrm{ml}$ of $3 \mathrm{M}$ perchloric acid at $0^{\circ} \mathrm{C}$. Extracts were kept on ice for $30 \mathrm{~min}$, then diluted by addition of $0.5 \mathrm{ml}$ deionized water. Extracts of incubation medium were prepared by adding concentrated perchloric acid to a final concentration of $0.6 \mathrm{M}$. After centrifugation, supernatants were removed from the precipitate, which was used for protein determination (to which all the metabolic data were normalized), and the $\mathrm{pH}$ was adjusted to 3.5 by adding $5 \mathrm{M}$ potassium formate. Buffered extracts were placed on ice, separated from sodium-potassium perchlorate, and stored at $4^{\circ} \mathrm{C}$ until assayed. The supernatant was assayed for lactate, pyruvate, and fructose by standard enzymatic methods (28, $29)$ and the lactate/pyruvate ratio (L/P) was calculated. Before fructose analysis, extracts were treated with glucose oxidase (30) to prevent interference with measurement of fructose by high glucose levels. The effect of elevated glucose levels on the cytosolic ratio of $\mathrm{NADH} / \mathrm{NAD}^{+}$was not measured directly, but was inferred from changes in the ratio of granulation tissue lactate/pyruvate; the cytosolic ratio of these metabolites is a more reliable parameter of the cytosolic ratio of free NADH/NAD ${ }^{+}$than measurement of the pyridine nucleotides themselves in tissue extracts (it is not possible to distinguish between mitochondrial and cytosolic pools, and the reduced and oxidized nucleotides are not extracted with equal efficiency because the reduced form is bound to enzymes more tightly than the oxidized form) (31).

\section{Statistical analysis}

All results are expressed as mean \pm SD of untransformed data. Overall differences among experimental groups for each parameter were first assessed by the Van der Waerden test $(32,33)$, and individual pair-wise group comparisons were evaluated by least square means analysis only if the Van der Waerden test was significant at $P<0.05$ for a given parameter. A nonparametric Blom transformation of data was performed before assessment of individual pair-wise group differences (34).

\section{Results}

VEGF antibody characterization. Both antibodies dose dependently inhibited ${ }^{125} \mathrm{I}-\mathrm{VEGF}$ binding to the Flt-1 receptor with half maximal inhibition at $0.3 \mu \mathrm{g} / \mathrm{ml}$ and $36 \mu \mathrm{g} / \mathrm{ml}$ for the monoclonal and polyclonal antibodies, respectively (Fig. $1 A$ ). In Fig. $1 B$, an increase in Fura-2 signal intensity was evident $\sim 15 \mathrm{~s}$ after addition of rhVEGF to human endothelial cells in suspension, reaching a fivefold increase by $60 \mathrm{~s}$, then slowly decaying over the next 2 min to a level two times baseline. The monoclonal antibody completely blocked the VEGF-induced increase in the Fura-2 signal, while the polyclonal antibody significantly delayed a rise in the signal which reached a level two times baseline 3 min after the addition of VEGF.

Effect of VEGF antibody on glucose- and sorbitol-induced permeability and blood flow changes. ${ }^{125}$ I-Albumin permeation and blood flow were increased $\sim 3$ - and 2.3-fold, respectively, by $30 \mathrm{mM}$ glucose vs $5 \mathrm{mM}$ glucose controls $(P<0.0001$ for both) (Fig. 2). The increased albumin permeation and blood flow caused by glucose were decreased in a dose-dependent manner by coadministration of a neutralizing polyclonal VEGF antibody with $30 \mathrm{mM}$ glucose. Increased albumin permeation induced by $30 \mathrm{mM}$ glucose was reduced by approximately one-half and the increased blood flow was reduced by two-thirds by coadministration of polyclonal or monoclonal VEGF antibodies at a concentration of $30 \mu \mathrm{g} / \mathrm{ml}$. Both the
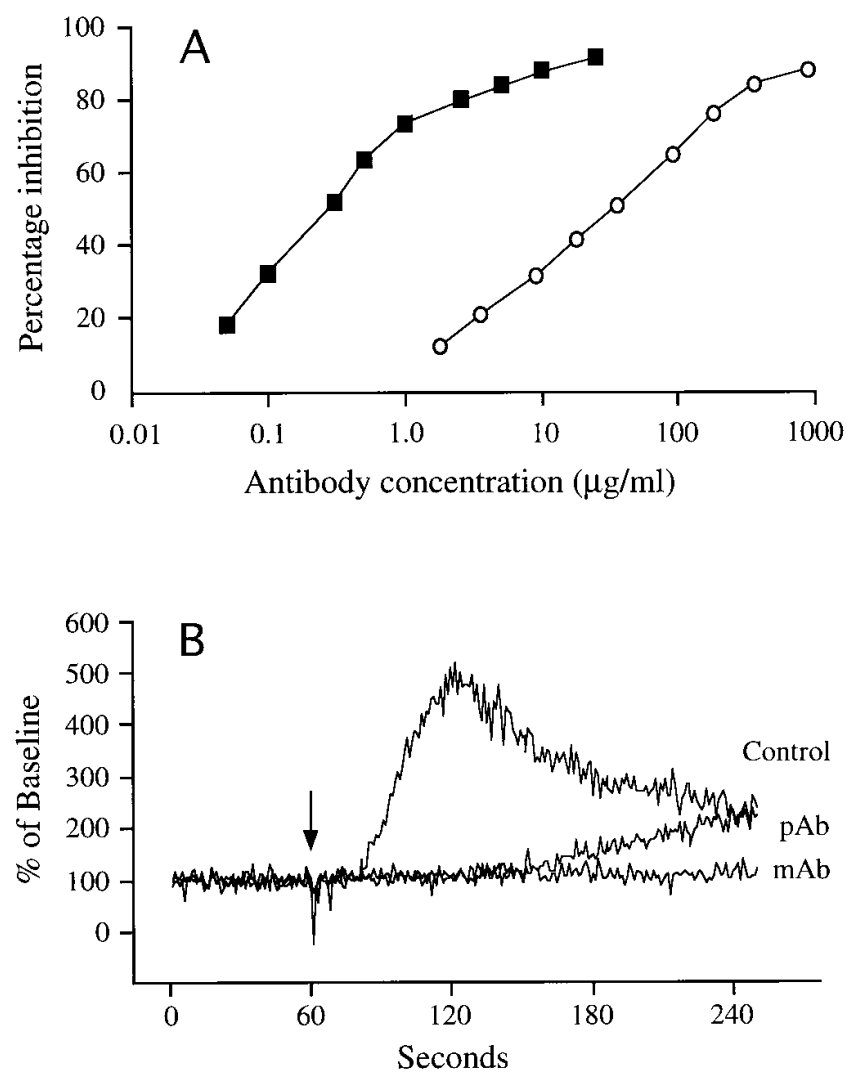

Figure 1. Inhibition of ${ }^{125}$ I-VEGF binding to Flt-1 receptor $(A)$ by increasing concentrations of VEGF polyclonal (open circles) and monoclonal (closed squares) antibodies. Data plotted represent a mean of two separate experiments with each antibody concentration measured in duplicate in each experiment. $(B)$ Representative Fura-2 fluorescence tracings (expressed as a percentage of baseline) demonstrating the prevention of $10 \mathrm{ng} / \mathrm{ml}$ VEGF-induced calcium release within human endothelial cells in suspension by VEGF mAb and a significant attenuation of the signal by polyclonal (pAb) antibody. Application of VEGF is indicated by the arrow.

polyclonal and monoclonal VEGF antibodies had no effect on albumin permeation or blood flow when coadministered with $5 \mathrm{mM}$ glucose at concentrations of 100 and $30 \mu \mathrm{g} / \mathrm{ml}$, respectively; nonspecific rabbit antibody $(100 \mu \mathrm{g} / \mathrm{ml})$ had no effect on vascular changes induced by $30 \mathrm{mM}$ glucose. We have previously reported that topical application of $30 \mathrm{mM} \mathrm{L}$-glucose (a nonmetabolizable stereoisomer of $\mathrm{D}$-glucose that penetrates cells much more slowly than D-glucose) and $30 \mathrm{mM} 3-0$-methylglucose (a nonmetabolizable analogue of D-glucose that is transported into cells at rates similar to those for D-glucose by the same glucose transporters) did not affect albumin permeation or blood flow (9).

Albumin permeation was increased 2.4-fold and blood flow 3-fold following application of $1 \mathrm{mM}$ sorbitol for $7 \mathrm{~d}$ vs $5 \mathrm{mM}$ glucose $(P<0.0001$ for both) (Fig. 3). The sorbitol dehydrogenase inhibitor, CP-166,572, prevented sorbitol-induced permeability changes and decreased blood flow by $88 \%$. Polyclonal VEGF antibody $(30 \mu \mathrm{g} / \mathrm{ml})$ coadministered with sorbitol decreased albumin hyperpermeability by $75 \%$ and blood flow by $81 \%$. 

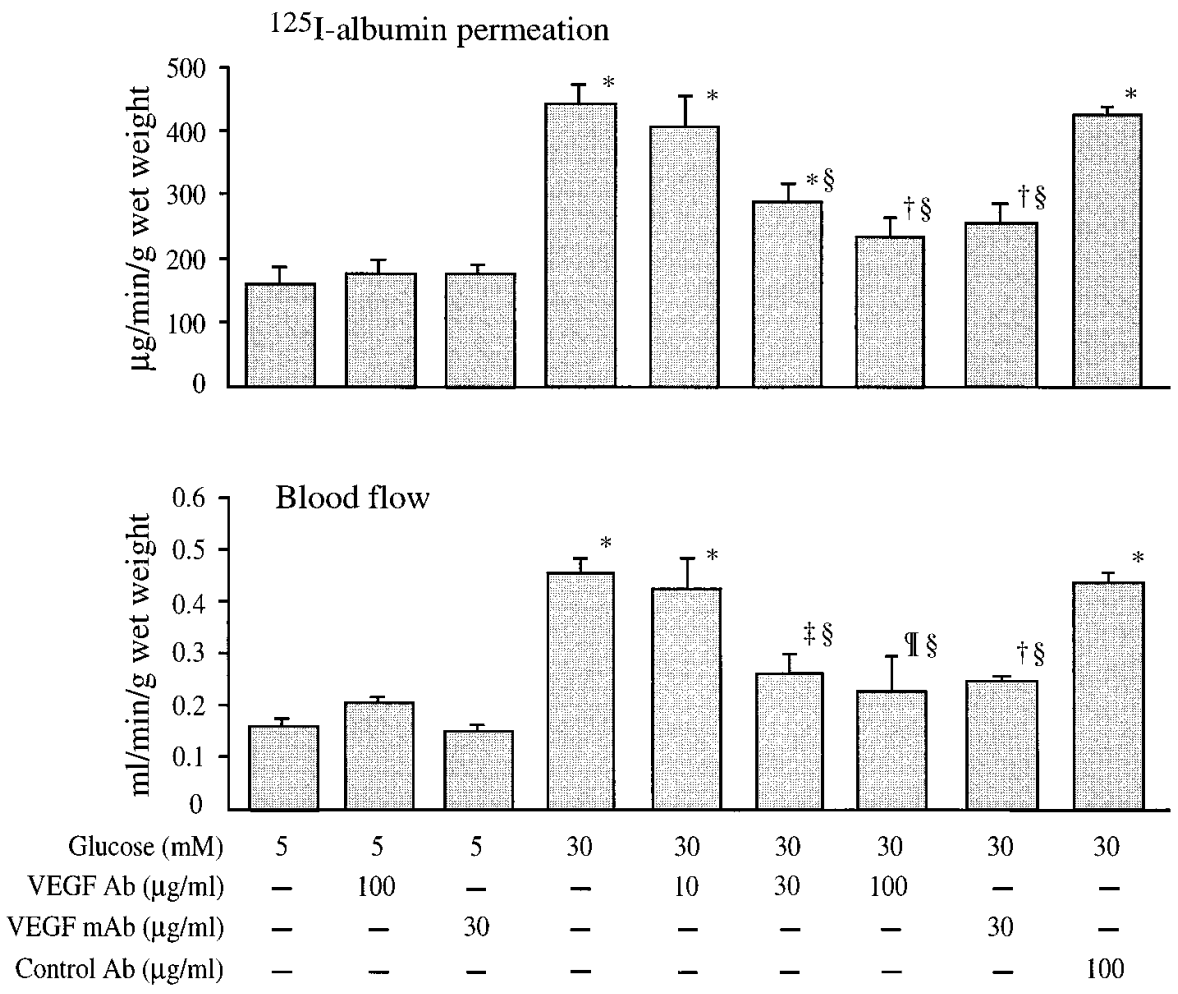

Figure 2. Effects of increasing concentration of neutralizing VEGF antibodies on glucose-induced increases in ${ }^{125} \mathrm{I}$-albumin permeation and blood flow in granulation tissue. Results are mean \pm SD. $5 \mathrm{mM}$ glucose, $n=14 ; 5 \mathrm{mM}$ glucose $+100 \mu \mathrm{g} / \mathrm{ml}$ polyclonal VEGF Ab, $n=3 ; 5 \mathrm{mM}$ glucose + $30 \mu \mathrm{g} / \mathrm{ml}$ monoclonal VEGF Ab, $n=3 ; 30$ mM glucose, $n=14 ; 30 \mathrm{mM}$ glucose +10 $\mu \mathrm{g} / \mathrm{ml} \mathrm{VEGF} \mathrm{Ab,} n=6 ; 30 \mathrm{mM}$ glucose + $30 \mu \mathrm{g} / \mathrm{ml}$ VEGF Ab, $n=6 ; 30 \mathrm{mM}$ glucose $+100 \mu \mathrm{g} / \mathrm{ml} \mathrm{VEGF} \mathrm{Ab,} n=7 ; 30 \mathrm{mM}$ glucose $+30 \mu \mathrm{g} / \mathrm{ml}$ monoclonal VEGF $\mathrm{Ab}, n=3 ; 30 \mathrm{mM}$ glucose $+100 \mu \mathrm{g} / \mathrm{ml}$ control $\mathrm{Ab}, n=4$. The Van der Waerden test indicated significant group differences for ${ }^{125}$ I-BSA permeation and blood flow $(P<0.0001$ for both $)$. Significantly different from $5 \mathrm{mM}$ glucose controls by least square means analysis: $* P<0.0001 ;{ }^{\dagger} P<$ $0.0002 ;{ }^{\ddagger} P<0.001 ;{ }^{\dddot{I}} P<0.01$. Significantly different from untreated $30 \mathrm{mM}$ glucose by least square means analysis: ${ }^{\S} P<0.0001$.

Effects of topical VEGF application to granulation tissue. As shown in Fig. 4, a single topical application of $100 \mathrm{pM}$ VEGF increased ${ }^{125} \mathrm{I}$-albumin permeation 2.8 -fold and blood flow 2.5 -fold ( $P<0.0001$ for both vs $5 \mathrm{mM}$ glucose controls) after $1 \mathrm{~h}$ of treatment. The hyperpermeability effect was decreased $55 \%$ and the blood flow effect was blocked completely when 100 pM VEGF was combined with $30 \mu \mathrm{g} / \mathrm{ml}$ VEGF monoclonal antibody for $20 \mathrm{~min}$ at $37^{\circ} \mathrm{C}$ before adding to granulation tissue. Two NOS inhibitors, $2 \mathrm{mM}$ L-NMMA and 1 $\mathrm{mM}$ aminoguanidine, when administered $2 \mathrm{~h}$ before and again during the VEGF application, completely blocked VEGFinduced increases in blood flow; increases in ${ }^{125} \mathrm{I}$-albumin permeation were prevented completely by L-NMMA and markedly attenuated ( $P<0.005$ vs VEGF treated) by aminoguanidine. Twice a day topical application of L-NMMA and aminoguanidine for $7 \mathrm{~d}$ did not affect permeability or blood flow in control granulation tissue (data not shown).

Effects of superoxide on vascular dysfunction. These experiments explored potential links between increased sorbitol pathway activity and reactive oxygen intermediate-derived mechanisms involving VEGF and nitric oxide. SOD reduced the 2.9-fold increase in ${ }^{125} \mathrm{I}$-albumin permeation produced by $30 \mathrm{mM}$ glucose and $1 \mathrm{mM}$ sorbitol by $\sim 90 \%(P<0.0001$ vs both) and decreased the 3.3-fold increase in blood flow by

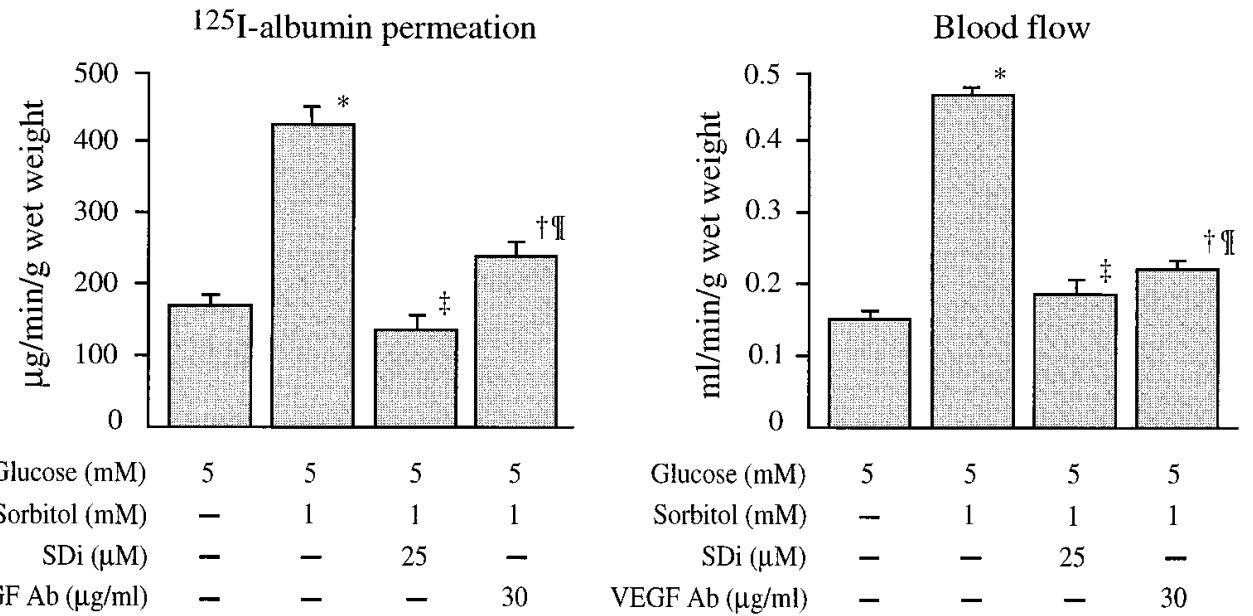

Figure 3. Effects of a sorbitol dehydrogenase inhibitor, CP-166,572, and a neutralizing, polyclonal VEGF antibody on sorbitol-induced increases in ${ }^{125}$ I-albumin permeation and blood flow in granulation tissue. Results are mean \pm SD. $5 \mathrm{mM}$ glucose, $n=8 ; 1 \mathrm{mM}$ sorbitol, $n=9 ; 1 \mathrm{mM}$ sorbitol $+25 \mu \mathrm{M}$ sorbitol dehydrogenase inhibitor (SDi), $n=6 ; 1 \mathrm{mM}$ sorbitol + $30 \mu \mathrm{g} / \mathrm{ml}$ polyclonal VEGF antibody, $n=6$. The Van der Waerden test indicated significant group differences for ${ }^{125}$ I-BSA permeation $(P<0.0001)$ and blood flow $(P<0.0004)$.

Significantly different from $5 \mathrm{mM}$ glucose controls by least square means analysis: $* P<0.0001 ;{ }^{\dagger} P<0.0004$. Significantly different from $1 \mathrm{mM}$ sorbitol by least square means analysis: ${ }^{\ddagger} P<0.0001 ;{ }^{\mathbb{T}} P<0.0006$. 
125I-albumin permeation

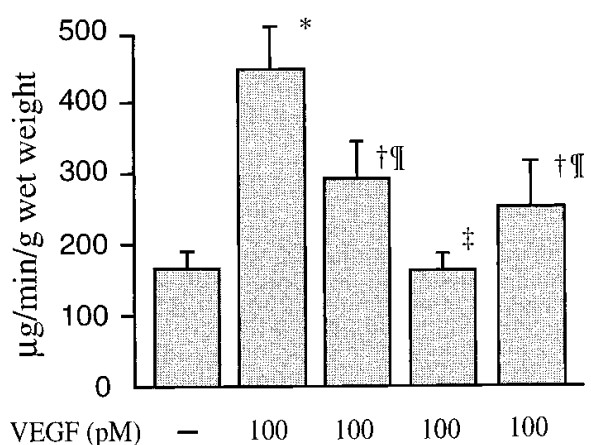

\section{Blood flow}

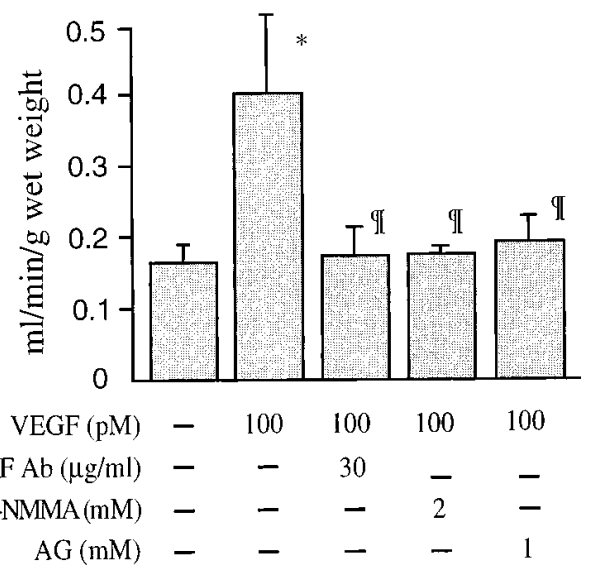

Figure 4. Effects of topically applied VEGF, VEGF + NOS inhibitors ( $A G$ and $L-N M M A)$, and VEGF + VEGF monoclonal antibody on vascular ${ }^{125}$ I-albumin permeation and blood flow in granulation tissue. Results are mean \pm SD. Control, $n=6 ; 100 \mathrm{pM}$ VEGF, $n=7$; $100 \mathrm{pM}$ VEGF $+2 \mathrm{mM}$ L-NMMA, $n=3 ; 100 \mathrm{pM}$ VEGF $+1 \mathrm{mM} \mathrm{AG}, n=5$; $100 \mathrm{pM}$ VEGF $+30 \mu \mathrm{g} / \mathrm{ml}$ VEGF antibody, $n=3$. The Van der Waerden test indicated significant group differences for ${ }^{125}$ I-BSA permeation and blood flow $(P<0.001$ and $P<0.004$, respectively). Significantly different from controls by least square means analysis: $* P<$ $0.0001 ;{ }^{\dagger} P<0.005$. Significantly different from untreated VEGF by least square means analysis: ${ }^{\ddagger} P<0.0001 ;{ }^{\pi} P<0.005$. $\sim 85 \%$ ( $P<0.0001$ vs both) (Fig. 5). The superoxide generating system, hypoxanthine plus xanthine oxidase in $5 \mathrm{mM}$ glucose, applied topically twice a day for $3 \mathrm{~d}$ to granulation tissue, produced similar increases in ${ }^{125} \mathrm{I}$-albumin permeation and blood flow observed with elevated glucose and sorbitol levels. The NOS inhibitors aminoguanidine and L-NMMA prevented these increases, while the neutralizing, monoclonal VEGF antibody reduced the superoxide-induced changes in ${ }^{125} \mathrm{I}$-albumin permeation and blood flow by $\sim 60 \%$ ( $P<0.02$ vs hypoxanthine + xanthine oxidase).

Effects of nitroprusside and A23187. Since VEGF stimulates intracellular calcium mobilization and increasing evidence in-
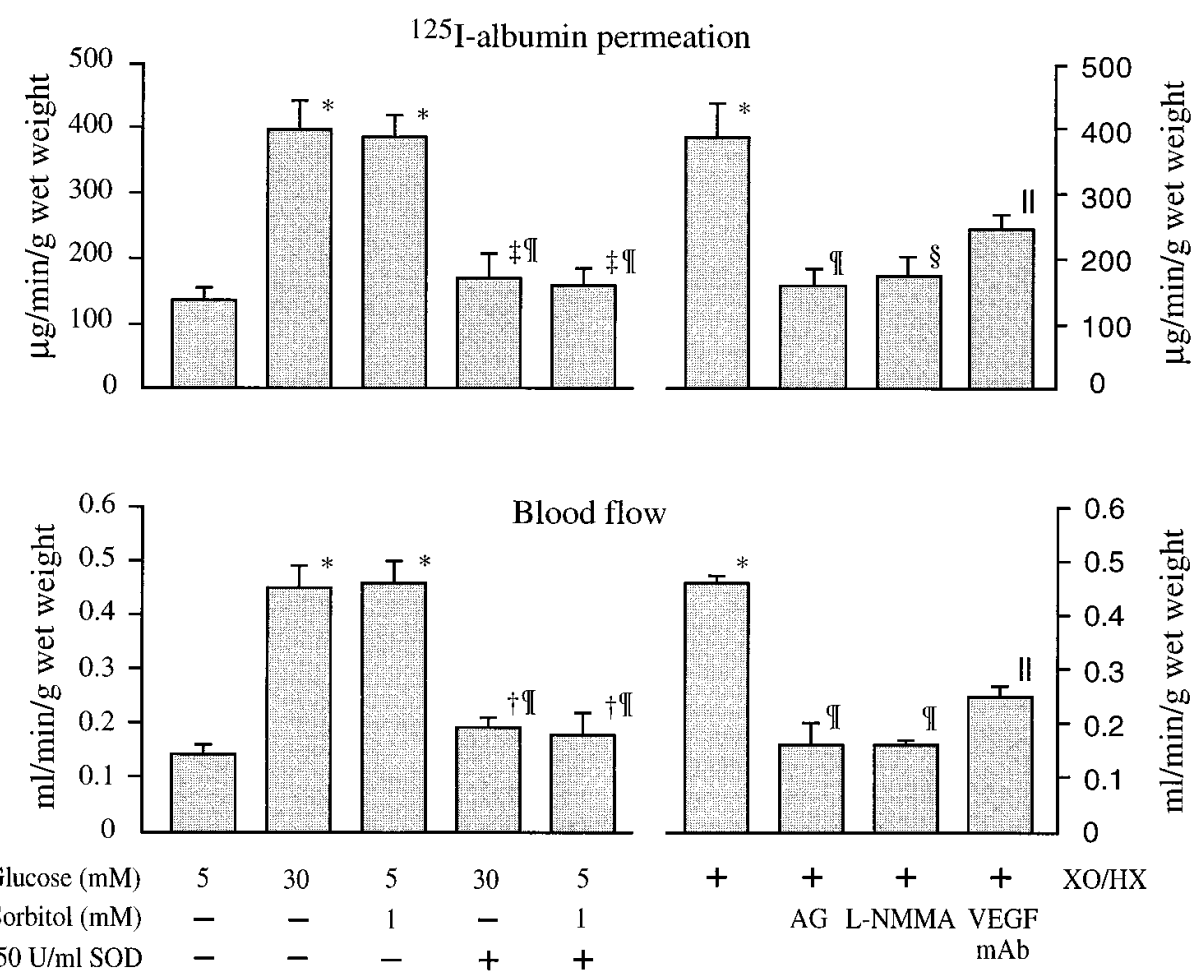

Figure 5. Effects of: (left) SOD on glucose- and sorbitol-induced increases in vascular ${ }^{125} \mathrm{I}$-albumin permeation and blood flow, and (right) NOS inhibitors and neutralizing VEGF antibody on superoxide-induced increases in vascular ${ }^{125} \mathrm{I}$-albumin permeation and blood flow in granulation tissue. Results are mean \pm SD. $5 \mathrm{mM}$ glucose control, $n=18 ; 30 \mathrm{mM}$ glucose, $n=18$; $1 \mathrm{mM}$ sorbitol, $n=12 ; 30 \mathrm{mM}$ glucose + $150 \mathrm{U} / \mathrm{ml} \mathrm{SOD}, n=6 ; 1 \mathrm{mM}$ sorbitol + $150 \mathrm{U} / \mathrm{ml} \mathrm{SOD}, n=9 ; 10 \mathrm{mM}$ hypoxanthine $(H X)+500 \mathrm{mU}$ xanthine oxidase $(X O / H X), n=8 ; \mathrm{XO} / \mathrm{HX}+1 \mathrm{mM} \mathrm{AG}$, $n=3 ; \mathrm{XO} / \mathrm{HX}+1 \mathrm{mM} \mathrm{L-NMMA}$, $n=3 ; \mathrm{XO} / \mathrm{HX}+30 \mu \mathrm{g} / \mathrm{ml}$ neutralizing monoclonal antibody, $n=3$. The Van der Waerden test indicated significant group differences for ${ }^{125}$ I-BSA permeation and blood flow in the experiments assessing effects of SOD $(P<0.0001$ for both $)$ and in the experiments using $\mathrm{XO} / \mathrm{HX}(P<0.005$ for both). Significantly different from $5 \mathrm{mM}$ glucose control by least square means analysis: ${ }^{*} P<0.0001 ;{ }^{\dagger} P<0.003 ;{ }^{\ddagger} P<$ 0.04 . Significantly different from $30 \mathrm{mM}$ glucose, $1 \mathrm{mM}$ sorbitol, or $\mathrm{XO} / \mathrm{HX}$ by least square means analysis: ${ }^{\text {I }} P<0.0001$; ${ }^{\S} P<0.0003, \| P<0.02$. 
125I-albumin permeation

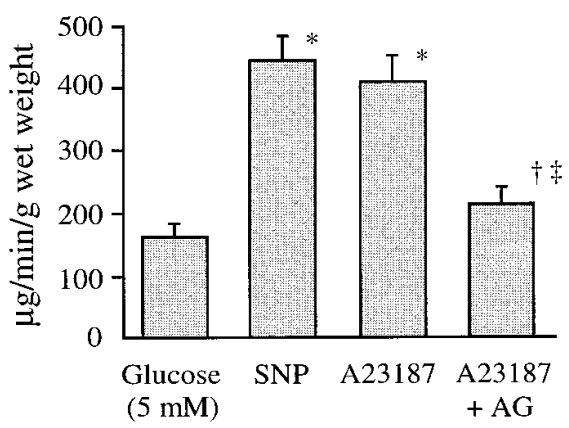

Blood flow

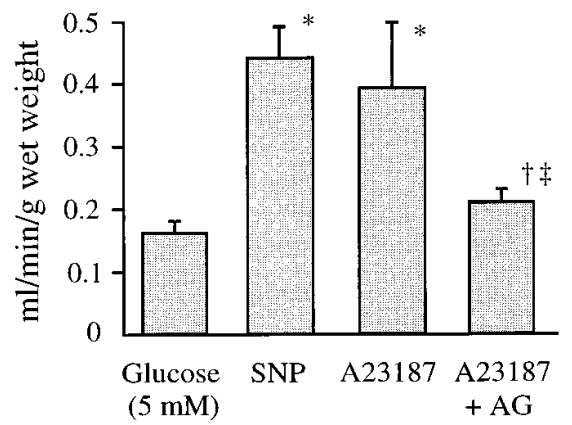

Figure 6. Effects of sodium nitroprusside $(S N P)$ and the calcium ionophore A23187 $\pm 1 \mathrm{mM}$ aminoguanidine on

${ }^{125} \mathrm{I}$-albumin permeation and blood flow in granulation tissue. Results are mean \pm SD. $5 \mathrm{mM}$ glucose control, $n=9$; SNP, $n=6$; $\mathrm{A} 23187, n=6$; $\mathrm{A} 23187+1 \mathrm{mM} \mathrm{AG}$, $n=3$. The Van der Waerden test indicated significant group differences for ${ }^{125}$ I-BSA permeation and blood flow $(P<0.0005$ and $P<0.001$, respectively). Significantly different from $5 \mathrm{mM}$ glucose controls by least square means analysis: $* P<0.0001 ;{ }^{\dagger} P<0.05$. Significantly different from untreated $\mathrm{A} 23187$ by least square means analysis: ${ }^{\ddagger} P<0.05$.
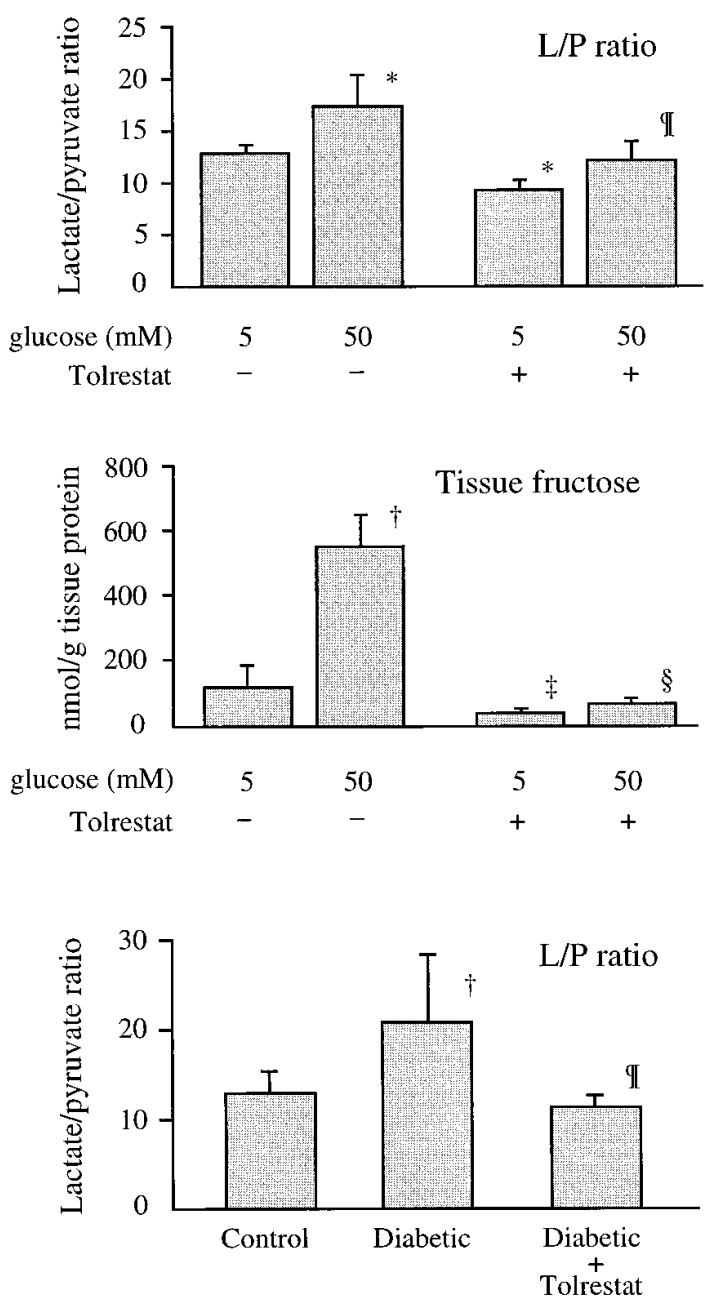

Figure 7. Lactate/pyruvate $(L / P)$ ratio and tissue fructose in granulation tissue (from control rats and from rats fed $0.2 \mathrm{mmol}$ tolrestat $/ \mathrm{kg}$ body weight added to the diet for $6 \mathrm{~d}$ ) after 2 -h incubation in 5 or 50 $\mathrm{mM}$ glucose. Granulation tissue fructose is expressed as nanomoles/ gram of tissue protein, and data are shown as the mean \pm 1 SD $(n=6$ per experimental group). Also shown is L/P ratio in granulation tissue sampled from control $(n=13)$, untreated diabetic $(n=13)$, and diabetic rats treated with tolrestat $(n=12)$. The Van der Waerden test indicated significant group differences for lactate/pyruvate $(P<$ $0.004)$ and tissue fructose $(P<0.002)$ obtained from granulation tis- dicates that vascular effects of VEGF are mediated via nitric oxide (17), these experiments were designed to assess effects of intracellular calcium mobilization and nitric oxide on vascular dysfunction. Topical application of $1 \mathrm{mM}$ sodium nitroprusside (two times daily for $1 \mathrm{wk}$ ) or $0.1 \mu \mathrm{M}$ A23187 (applied once for $1 \mathrm{~h}$ ) produced similar increases in ${ }^{125} \mathrm{I}$-albumin permeation (2.7-fold) and blood flow (2.6-fold) $(P<0.0001$ vs controls; Fig. 6). These increases were comparable to those induced by $30 \mathrm{mM}$ glucose and $1 \mathrm{mM}$ sorbitol. Aminoguanidine (1 mM) decreased the A23187-induced blood flow and permeability increases by $80 \%$ ( $P<0.05$ for both vs A23187).

Granulation tissue metabolites. These experiments assessed sorbitol pathway-linked reductive stress in granulation tissue. Incubating granulation tissue in $50 \mathrm{mM}$ glucose increased the $\mathrm{L} / \mathrm{P}$ ratio $36 \%(P<0.0003$ vs $5 \mathrm{mM}$ glucose control $)$ and tissue fructose approximately fivefold $(P<0.0008$ vs control) (Fig. 7). Tolrestat prevented the increased $\mathrm{L} / \mathrm{P}$ ratio induced by 50 $\mathrm{mM}$ glucose and reduced the $\mathrm{L} / \mathrm{P}$ ratio by $27 \%$ in tissues incubated in $5 \mathrm{mM}$ glucose $(P<0.0002)$. A similar pattern was observed for tissue fructose: tolrestat prevented the $50 \mathrm{mM}$ glucose-induced increase and decreased tissue fructose levels versus untreated $5 \mathrm{mM}$ glucose controls $(P<0.05)$. Streptozotocin-induced diabetes resulted in a $63 \%$ increase in granulation tissue $\mathrm{L} / \mathrm{P}$ ratio versus controls $(P<0.001)$, which was completely prevented by tolrestat.

\section{Discussion}

The important observations in this study are that vascular dysfunction induced by elevated tissue glucose or sorbitol levels and by increased levels of reactive oxygen intermediates is significantly attenuated by neutralizing antibodies to VEGF, and that acute VEGF-, superoxide-, and calcium ionophore-linked vascular changes are blocked by NOS inhibitors. These findings: $(a)$ indicate that metabolic imbalances linked to increased

sue incubated in vitro with $50 \mathrm{mM}$ glucose, and for $\mathrm{L} / \mathrm{P}$ ratio of granulation tissue obtained from control and diabetic rats $(P<0.0002)$. Significantly different from controls by least square means analysis: ${ }^{*} P<0.0005 ;{ }^{\dagger} P<0.001 ;{ }^{\ddagger} P<0.05$. Significantly different from untreated $50 \mathrm{mM}$ glucose or untreated diabetic rats by least square means analysis: ${ }^{\mathbb{}} P<0.0001 ;{ }^{\S} P<0.001$. 
sorbitol pathway activity increase either the expression, activity, or sensitivity of this growth factor (in the absence of true hypoxia) sufficiently to cause vascular dysfunction, (b) implicate VEGF in mediating vascular dysfunction induced by elevated glucose levels via reactive oxygen intermediate-derived mechanisms and via nitric oxide produced by increased NOS activity, and (c) suggest that VEGF may play an important role in the pathogenesis of early diabetic vascular dysfunction (i.e., hemodynamic changes and loss of endothelial barrier functional integrity) before development of vascular structural changes.

Mechanism(s) of glucose-induced increased VEGF production. The findings that VEGF expression is increased in ischemic areas surrounding regions of tumor necrosis (reviewed in reference 16) as well as in hypoxic tissues (35-38), together with numerous observations that limiting oxygen concentration provokes a number of cell types to overexpress VEGF mRNA $(19,20,39)$ indicate that local tissue hypoxia is a major regulator of VEGF production. However, the molecular mechanisms responsible for hypoxia-induced increased VEGF mRNA expression have not been fully elucidated. Despite indirect evidence suggesting that the hypoxia sensing elements for VEGF and other hypoxia-inducible genes occur through a heme-containing protein such as the superoxide-generating flavoprotein NADPH oxidase (40), the identity of the hypoxia sensor for VEGF remains unknown.

Since hypoxia is a potent stimulus for increased VEGF expression, and since the redox imbalance (an increased ratio of $\mathrm{NADH} / \mathrm{NAD}^{+}$) resulting from impaired oxidation of NADH to $\mathrm{NAD}^{+}$by the electron transport chain is a very early consequence of hypoxia, a plausible explanation for increased VEGF production by tissues exposed to elevated glucose levels is the "hypoxia-like" redox imbalance resulting from increased flux of glucose via the sorbitol pathway (see Fig. 8). To the extent that an increased cytosolic ratio of free NADH/ $\mathrm{NAD}^{+}$may be involved in mediating hypoxia-induced VEGF expression, then excess reducing equivalents generated by any metabolic imbalance might be predicted to increase VEGF mRNA expression. While many metabolic imbalances associated with the diabetic milieu may generate excess reducing equivalents (12), the best characterized example is increased oxidation of sorbitol to fructose coupled to reduction of $\mathrm{NAD}^{+}$to NADH by sorbitol dehydrogenase in the second step of the sorbitol pathway. This redox imbalance has been demonstrated in retina, kidney, and nerve (as well as in granulation tissue in this report) exposed to elevated glucose levels in vivo and in vitro, and has been linked to increased flux of glucose via the sorbitol pathway in each tissue (41-43). Furthermore, vascular dysfunction in each of these tissues in diabetic as well as in nondiabetic rats with acute hyperglycemia of $5 \mathrm{~h}$ duration (induced by i.v. glucose infusion) is attenuated by inhibitors of the sorbitol pathway. It is noteworthy that interventions which prevent sorbitol pathway-linked vascular dysfunction either prevent cytosolic reductive stress (i.e., inhibitors of aldose reductase and sorbitol dehydrogenase prevent reduction of $\mathrm{NAD}^{+}$to $\mathrm{NADH}$ while pyruvate increases the rate of oxidation of $\mathrm{NADH}$ to $\mathrm{NAD}^{+}$by lactate dehydrogenase), or they inhibit some step in the cascade of biochemical imbalances that result from cytosolic reductive stress as depicted in Fig. 8. A number of other diabetes-induced metabolic imbalances implicated in the pathogenesis of diabetic complications also are potential consequences of the effects of re-

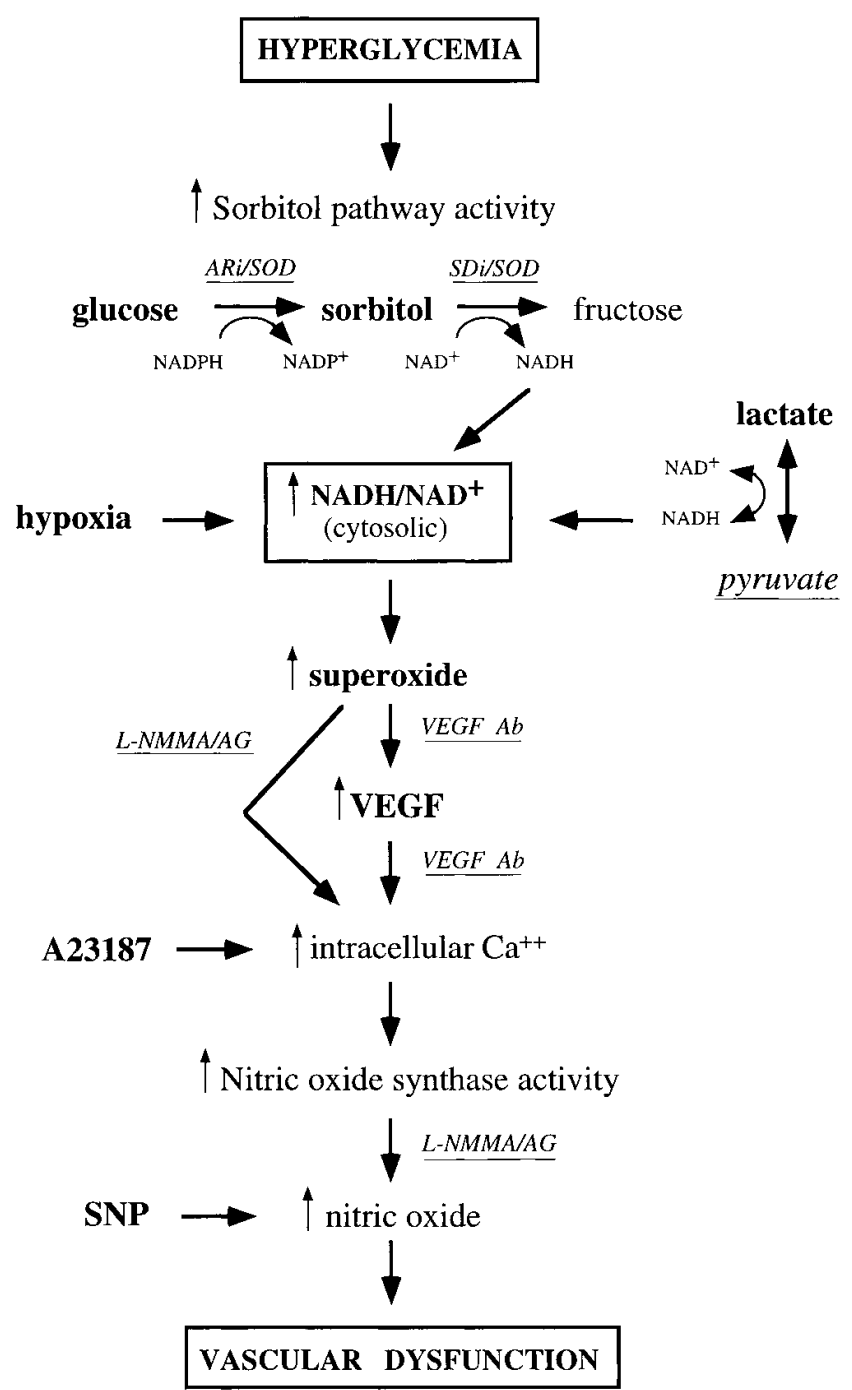

Figure 8. Tentative scenario for linkage of metabolic imbalances that mediate the effects of hyperglycemia on vascular dysfunction. Compounds which produce vascular injury include glucose, sorbitol, lactate (data not shown), VEGF, superoxide, A23187, and SNP and are shown in bold face. Interventions which block glucose-induced vascular dysfunction are shown in italics and underlined, and include aldose reductase inhibitor (ARi), sorbitol dehydrogenase inhibitor (SDi), SOD, pyruvate, VEGF Ab, and the NOS inhibitors L-NMMA and $\mathrm{AG}$.

ductive stress on other dehydrogenase enzymes. Increased $\mathrm{NADH} / \mathrm{NAD}^{+}:$( a ) favors inhibition of glyceraldehyde 3-phosphate dehydrogenase, causing accumulation of triose phosphates (12) which are among the most potent intracellular nonenzymatic glycation agents known; (b) promotes reduction of dihydroxyacetone phosphate to sn-glycerol 3-phosphate, the first step in one pathway for de novo synthesis of diacylglycerol, an activator of protein kinase C; and $(c)$ inhibits xanthine dehydrogenase which favors oxidation of xanthine and hypoxanthine by xanthine oxidase resulting in production of superoxide.

Evidence that hypoxia, ischemia/reperfusion injury, and diabetes/hyperglycemia sequentially induce reductive stress and oxidative stress raises the possibility that reductive stress- 
induced increased production of reactive oxygen intermediates may mediate the increased VEGF in these conditions. The plausibility of this scenario is supported by several lines of evidence: $(a)$ reductive stress increases superoxide production by several mechanisms (12) including inhibition of xanthine dehydrogenase as discussed above; $(b)$ reactive oxygen intermediates increase VEGF mRNA expression (44); (c) superoxide dismutase and VEGF antibodies prevent vascular dysfunction induced by elevated glucose and sorbitol levels in the skin chamber granulation tissue (Figs. 2, 3, and 5); and (d) neutralizing VEGF antibody prevents vascular dysfunction induced by reactive oxygen intermediates (Fig. 5).

An alternative putative mechanism of sorbitol pathwaylinked oxidative stress has been proposed to result from competition between aldose reductase, glutathione reductase, and nitric oxide synthase for the cofactor NADPH (45). However, there is little evidence that NADPH levels are limiting for glutathione reductase or nitric oxide synthase activity in the two tissues in which it has been measured; in lenses of diabetic rats NADPH levels have been reported to be slightly decreased (46), and in peripheral nerve NADPH levels and NADPH/ $\mathrm{NADP}^{+}$ratios have been reported to be normal (43). While it remains unclear at this time if accelerated sorbitol pathway activity decreases cytosolic NADPH sufficiently to impact on the activities of GSH reductase and NO synthase in vascular cells, the relatively low $K_{\mathrm{m}}$ 's of aldose reductase $(\sim 4 \mu \mathrm{M})$, glutathione reductase $(\sim 10 \mu \mathrm{M})$, and nitric oxide synthase $(\sim 0.3$ $\mu \mathrm{M})$ for the cofactor NADPH, suggests that the modest reduction in NADPH observed in diabetic tissues would not limit the activities of these enzymes.

Mechanisms of VEGF-mediated vascular dysfunction induced by elevated glucose levels. The mechanism(s) by which VEGF exerts its mitogenic, hemodynamic, and vascular permeability effects on vascular endothelium remain poorly understood, although increasing evidence suggests that these effects of VEGF are mediated, at least in part, via nitric oxide. It has been shown that both recombinant and native VEGF induce a slowly developing relaxation in isolated canine coronary arteries that is dependent on intact endothelium, and this can be blocked by NOS inhibitors as well as by a neutralizing VEGF antibody (17). VEGF induces relaxation in canine coronary arteries by stimulating nitric oxide release, most likely via increases in intracellular calcium, events that are initiated by VEGF receptor-induced tyrosine phosphorylation of phospholipase C- $\gamma 1$. These observations are consistent with reports that: (a) VEGF-stimulated proliferation of coronary venular endothelium is mediated by the formation of nitric oxide and cGMP, and that the VEGF proliferative effect could be blocked with NOS inhibitors (47); (b) human monocyte-induced angiogenesis requires an L-arginine/NOS-dependent mechanism (48); (c) agonist-induced activation of NOS as well as nitric oxide donors promote endothelial cell proliferation, whereas NOS inhibitors suppress the response (49); and (d) systemic administration of VEGF in rats decreased blood pressure, cardiac output, and stroke volume without affecting myocardial contractility and these changes were attenuated with NOS inhibitors (50).

The findings that neutralizing VEGF antibodies decreased albumin permeation and blood flow induced by elevated glucose and sorbitol levels as well as by increased superoxide levels support the conclusion that these vascular changes are mediated, at least in part, by increased VEGF production. The likelihood that these vascular changes are mediated by VEGFinduced stimulation of NOS as depicted in Fig. 8 is supported by several lines of evidence. First, vascular dysfunction induced by elevated glucose levels was prevented by two different neutralizing antibodies to VEGF (Fig. 2) and, as previously reported, by two different NOS inhibitors (51). Vascular dysfunction induced by VEGF also was prevented by these same NOS inhibitors, i.e., aminoguanidine and L-NMMA (Fig. 4). In addition, the nitric oxide releasing agent sodium nitroprusside and the calcium ionophore A23187 caused the same vascular dysfunction induced by glucose, sorbitol, and VEGF, and the effects of A23187 were prevented by aminoguanidine (Fig. $6)$. These observations support the conclusion that elevated glucose levels can increase VEGF production sufficiently to cause vascular dysfunction in the absence of hypoxia. This interpretation is consistent with recent evidence that elevated glucose increases VEGF in retinal pigment epithelial cells (52) and increases platelet-derived growth factor- $\beta$ mRNA in human monocytes, capillary endothelial cells, and rat mesangial cells (53). Shweiki et al. (54) published evidence of a significant glucose induction of VEGF mRNA under normoxic conditions in a cell line derived from a rat glial tumor (Fig. 3 in reference 54), but did not comment on the significance of this finding.

The effects of increased sorbitol pathway metabolism on nitric oxide production are controversial and are due, at least in part, to differences in models used (tissue culture, isolated vascular rings, whole animal, and human studies) and to the in vivo use of nonselective inhibitors of NOS at doses which induce hypertension (45). Our finding that VEGF-induced vascular dysfunction is prevented by NOS inhibitors is consistent with evidence that a relative or absolute increase in nitric oxide mediates vascular dysfunction in diabetic rats and in retina and nerve of nondiabetic rats with acute hyperglycemia (27, 55). Our hypothesis that vascular dysfunction induced by early diabetes is mediated by increased nitric oxide production as a consequence of "hypoxia-like" cytosolic reductive stress is supported by evidence that true hypoxia increases endothelial NOS mRNA, NOS enzyme activity, and increased NO production $(56,57)$ and that blood flow increases immediately in response to mild hypoxia.

While aminoguanidine blocked glucose-, VEGF-, superoxide- and A23187-induced increases in albumin hyperpermeability and blood flow, this effect was not mediated by blocking VEGF binding to its receptor, nor did aminoguanidine interfere with VEGF-induced changes in intracellular calcium and release of van Willebrand factor (unpublished observations). These results suggest that the beneficial effect of aminoguanidine is through inhibition of constitutive NOS, whose activity is increased by changes in intracellular calcium after stimulation with VEGF, superoxide, or the calcium ionophore A23187. The observation that L-NMMA also blocked VEGFinduced vascular changes provides further support for this interpretation. Although aminoguanidine is a selective inhibitor of the inducible isoform of NOS, this selectivity depends on the absence of $\mathrm{Ca}^{2+}$. In the presence of $\mathrm{Ca}^{2+}$, aminoguanidine competes with L-arginine for cNOS (58), and at the doses used in the present studies, aminoguanidine also effectively inhibits constitutive NOS.

In conclusion, these observations provide evidence that vascular dysfunction induced by elevated tissue glucose levels is mediated, at least in part, by VEGF via mechanisms involv- 
ing increased superoxide and nitric oxide production. This finding supports the hypothesis that hypoxia-like reductive stress induced by hyperglycemia, linked to increased sorbitol pathway activity, increases VEGF production enough to cause vascular dysfunction manifested by increased blood flow and impaired vascular barrier functional integrity.

\section{Acknowledgments}

We thank Nemani Rateri and Antoinette Faller for expert assistance with mounting and treating granulation tissue skin chambers, and Wanda Allison for technical assistance with the animal surgery.

This research was supported in part by National Institutes of Health grant EY-06600 (J.R. Williamson) and by the Kilo Diabetes and Vascular Research Foundation.

\section{References}

1. Greene, D.A., S. Lattimer, J. Ulbrecht, and P. Carroll. 1985. Glucoseinduced alterations in nerve metabolism: current perspective on the pathogenesis of diabetic neuropathy and future directions for research and therapy. Diabetes Care. 8:290-299.

2. Winegrad, A.E. 1987. Does a common mechanism induce the diverse complications of diabetes? Diabetes. 36:396-406.

3. Kinoshita, J.H., and C. Nishimura. 1988. The involvement of aldose reductase in diabetic complications. Diabetes Metab. Rev. 4:323-337.

4. Pugliese, G., R.G. Tilton, and J.R. Williamson. 1991. Glucose-induced metabolic imbalances in the pathogenesis of diabetic vascular disease. Diabetes Metab. Rev. 7:35-59.

5. Ruderman, N.B., J.R. Williamson, and M. Brownlee. 1992. Glucose and diabetic vascular disease. FASEB J. 6:2905-2914.

6. Tilton, R.G., K. Chang, G. Pugliese, D.M. Eades, M.A. Province, W.R. Sherman, C. Kilo, and J.R. Williamson. 1989. Prevention of hemodynamic and vascular albumin filtration changes in diabetic rats by aldose reductase inhibitors. Diabetes. 38:1258-1270.

7. Pugliese, G., R.G. Tilton, A. Speedy, K. Chang, M.A. Province, C. Kilo, and J.R. Williamson. 1990. Vascular filtration function in galactose-fed versus diabetic rats: the role of polyol pathway activity. Metab. Clin. Exp. 39:690-697.

8. Tilton, R.G., K. Chang, J.R. Nyengaard, M. Van den Enden, Y. Ido, and J.R. Williamson. 1995. Inhibition of sorbitol dehydrogenase: effects on vascular and neural dysfunction in streptozocin-induced diabetic rats. Diabetes. 44:234 242.

9. Williamson, J.R., E. Ostrow, D.M. Eades, K. Chang, W. Allison, C. Kilo, and W.R. Sherman. 1990. Glucose-induced microvascular functional changes in nondiabetic rats are stereospecific and are prevented by an aldose reductase inhibitor. J. Clin. Invest. 85:1167-1172.

10. Williamson, J.R., K. Chang, E. Ostrow, W. Allison, J. Harlow, and C. Kilo. 1989. Sorbitol-induced increases in vascular albumin clearance are prevented by pyruvate but not myo-inositol. Diabetes. 38:94a. (Abstr.)

11. Wolf, B.A., J.R. Williamson, R.A. Easom, K. Chang, W.R. Sherman, and J. Turk. 1990. Diacylglycerol accumulation and microvascular abnormalities induced by elevated glucose levels. J. Clin. Invest. 87:31-38.

12. Williamson, J.R., K. Chang, M. Frangos, K.S. Hasan, Y. Ido, T. Kawamura, J.R. Nyengaard, M. Van den Enden, C. Kilo and R.G. Tilton. 1993. Hyperglycemic pseudohypoxia and diabetic complications. Diabetes. 42:801-813.

13. Bunger, R., R.T. Mallet, and D.A. Hartman. 1989. Pyruvate-enhanced phosphorylation potential and inotropism in normoxic and postischemic isolated working heart: near-complete prevention of reperfusion contractile failure. Eur. J. Biochem. 180:221-233.

14. Cavallini, L., M. Valente, and M.P. Rigobello. 1990. The protective action of pyruvate on recovery of ischemic rat heart: comparison with other oxidizable substrates. J. Mol. Cell. Cardiol. 22:143-154.

15. Ferrara, N. 1993. Vascular endothelial growth factor. Trends Cardiovasc. Med. 3:244-250.

16. Dvorak, H.F., L.F. Brown, M. Detmar, and A.M. Dvorak. 1995. Vascular permeability factor/vascular endothelial growth factor, microvascular hyperpermeability, and angiogenesis. Am. J. Pathol. 146:1029-1039.

17. Ku, D.D., J.K. Zaleski, S. Liu, and T.A. Brock. 1993. Vascular endothelial growth factor induces EDRF-dependent relaxation in coronary arteries. Am. J. Physiol. 265:H586-H592.

18. Minchenko, A., T. Bauer, S. Salceda, and J. Caro. 1994. Hypoxic stimulation of vascular endothelial growth factor expression in vitro and in vivo. $L a b$. Invest. 71:374-379.

19. Namiki, A., E. Brogi, M. Kearney, E.A. Kim, T. Wu, T. Couffinhal, L. Varticovski, and J.M. Isner. 1995. Hypoxia induces vascular endothelial growth factor in cultured human endothelial cells. J. Biol. Chem. 270:31189-31195.
20. Aiello, L.P., J.M. Northrup, B.A. Keyt, H. Takagi, and M.A. Iwamoto. 1995. Hypoxic regulation of vascular endothelial growth factor in retinal cells. Arch. Ophthalmol. 113:1538-1544.

21. Fiebich, B.L., B. Jäger, C. Schöllmann, K. Weindel, J. Wilting, G. Kochs, D. Marmé, H. Hug, and H.A. Weich. 1993. Synthesis and assembly of functionally active human vascular endothelial growth factor homodimers in insect cells. Eur. J. Biochem. 211:19-26.

22. Bjercke, R.J., G. Cook, N. Rychlik, H.B. Gjika, H.V. Vunakis, and J.J. Langone. 1986. Stereospecific monoclonal antibodies to nicotine and cotinine and their use in enzyme-linked immunosorbent assays. J. Immunol. Methods. 90:203-213

23. Koehler, G., and C. Milstein. 1976. Derivation of specific antibody-producing tissue culture and tumor lines by cell fusion. Eur. J. Immunol. 6:511-519.

24. Brock, T.A., and E. L. Capasso. 1988. Thrombin and histamine activate phospholipase $\mathrm{C}$ in human endothelial cells via a phorbol ester-sensitive pathway. J. Cell. Physiol. 136:54-62.

25. Brock, T.A., H. F. Dvorak, and D. R. Senger. 1991. Tumor-secreted vascular permeability factor increases cytosolic $\mathrm{Ca}^{2+}$ and von Willebrand factor release in human endothelial cells. Am. J. Pathol. 138:213-221.

26. Lundberg, C., and B. Gerdin. 1984. The inflammatory reaction in an experimental model of open wounds in the rat. The effect of arachidonic acid metabolites. Eur. J. Pharmacol. 97:229-238.

27. Tilton, R.G., K. Chang, K.S. Hasan, J.M. Petrash, T.P. Misko, W.M. Moore, M.G. Currie, J.A. Corbett, M.L. McDaniel, and J.R. Williamson. 1993. Prevention of diabetic vascular dysfunction by guanidines: inhibition of nitric oxide synthase versus advanced glycation end product formation. Diabetes. 42: 221-232.

28. Lowry, O.H., and J.V. Passoneau. 1972. A Flexible System of Enzymatic Analysis. Academic Press, Inc., Orlando, FL. 174.

29. Passonneau, J.V., and O.H. Lowry. 1993. Enzymatic Analysis. A Practical Guide. The Humana Press, Totowa, NJ.

30. Chi, M.M.-Y., M.E. Pusateri, J.G. Carter, B.J. Norris, D.B. McDougal, Jr., and O.H. Lowry. 1987. Enzymatic assays for 2-deoxyglucose and 2-deoxyglucose 6-phosphate. Anal. Biochem. 161:508-513.

31. Williamson, D.H., P. Lund, and H.A. Krebs. 1967. The redox state of free nicotinamide-adenine dinucleotide in the cytoplasm and mitochondria of rat liver. Biochem. J. 103:514-527.

32. Lehman, E.L. 1975. Nonparametrics: Statistical Methods Based on Ranks. Holden-Day, San Francisco.

33. Anderson, T.W. 1958. An Introduction to Multivariate Statistical Analysis. John Wiley \& Sons, Inc., New York.

34. Blom, G. 1958. Statistical Estimates and Transformed Beta Variables. John Wiley \& Sons, Inc., New York.

35. Phillips, H.S., M. Armanini, D. Stavrou, N. Ferrara, and M. Westphal. 1993. Intense focal expression of vascular endothelial growth factor mRNA in human intracranial neoplasms: association with regions of necrosis. Int. J. Oncol. 2:913-919.

36. Shweiki, D., A. Itin, D. Soffer, and E. Keshet. 1992. Vascular endothelial growth factor induced by hypoxia may mediate hypoxia-initiated angiogenesis. Nature (Lond.). 359:843-845.

37. Ladoux, A., and C. Frelin. 1993. Hypoxia is a strong inducer of vascular endothelial growth factor mRNA expression in the heart. Biochem. Biophys. Res. Commun. 195:1005-1010.

38. Plate, K.H., G. Breier, H.A. Weich, and W. Risau. 1992. Vascular endothelial growth factor is a potential tumour angiogenesis factor in vivo. Nature (Lond.). 359:845-847.

39. Koos, R.D., and C.E. Olson. 1991. Hypoxia stimulates expression of the gene for vascular endothelial growth factor (VEGF), a putative angiogenic factor, by granulosa cells of the ovarian follicle, a site of angiogenesis. J. Cell Biol. 115:421a. (Abstr.)

40. Goldberg, M., and T. Schneider. 1994. Similarities between the oxygen sensing mechanisms regulating the expression of vascular endothelial growth factor and erythropoietin. J. Biol. Chem. 269:4355-4359.

41. Tilton, R.G., L.M. Baier, J.E. Harlow, S.R. Smith, E. Ostrow, and J.R Williamson. 1992. Diabetes-induced glomerular dysfunction: links to a more reduced cytosolic redox state. Kidney Int. 41:778-788.

42. Van den Enden, M.K., J.R. Nyengaard, E. Ostrow, J.H. Burgan, and J.R. Williamson. 1995. Elevated glucose levels increase retinal glycolysis and sorbitol pathway metabolism. Invest. Ophthalmol. \& Visual Sci. 36:1675-1685.

43. Obrosova, I., J. Marvel, A.M. Faller, and J.R. Williamson. 1995. Reductive stress is a very early metabolic imbalance in sciatic nerve in diabetic and galactose-fed rats. Diabetologia. 38:8a. (Abstr.)

44. Kuroki, M., E.E. Voest, S. Amano, L.V. Beerepoot, S. Takashima, M Tolentino, R.Y. Kim, R.M. Rohan, K.A. Colby, K.-T. Yeo, and A.P. Adamis. 1996. Reactive oxygen intermediates increase vascular endothelial growth factor expression in vitro and in vivo. J. Clin. Invest. 98:1167-1175.

45. Stevens, M.J., J. Dananberg, E.L. Feldman, S.A. Lattimer, M. Kamijo, T.P. Thomas, H. Shindo, A.A.F. Sima, and D.A. Greene. 1994. The linked roles of nitric oxide, aldose reductase, and $\left(\mathrm{Na}^{+}, \mathrm{K}^{+}\right)$-ATPase in the slowing of nerve conduction in the streptozotocin diabetic rat. J. Clin. Invest. 94:853-859.

46. Lou, M.F., J.R. Dickerson, Jr., R. Garadi, and B.M. York, Jr. 1988. Glutathione depletion in the lens of galactosemic and diabetic rats. Exp. Eye Res. 
46:517-530.

47. Morbidelli, L., C.-H. Chang, J.G. Douglas, H.J. Granger, F. Ledda, and M. Ziche. 1996. Nitric oxide mediates mitogenic effect of VEGF on coronary venular endothelium. Am. J. Physiol. 270:H411-H415.

48. Leibovich, S.J., P.J. Polverini, T.W. Fong, L.A. Harlow, and A.E. Koch. 1994. Production of angiogenic activity by human monocytes requires an L-arginine/nitric oxide-synthase-dependent effector mechanism. Proc. Natl. Acad. Sci. USA. 91:4190-4194.

49. Ziche, M., L. Morbidelli, E. Masini, S. Amerini, H.J. Granger, C.A. Maggi, P. Geppetti, and F. Ledda. 1994. Nitric oxide mediates angiogenesis in vivo and endothelial cell growth and migration in vitro promoted by substance P. J. Clin. Invest. 94:2036-2044.

50. Yang, R., G.R. Thomas, S. Bunting, A. Ko, N. Ferrara, B. Keyt, J. Ross, and H. Jin. 1996. Effects of vascular endothelial growth factor on hemodynamics and cardiac performance. J. Cardiovasc. Pharmacol. 27:838-844.

51. Hasan, K.S., K. Chang, W. Allison, A. Faller, J.V. Santiago, R.G. Tilton, and J.R. Williamson. 1993. Glucose-induced increases in regional blood flow are prevented by aminoguanidine and L-NMMA, inhibitors of nitric oxide synthase. FASEB J. 7:105a. (Abstr.)

52. Sone, S., Y. Kawakami, Y. Okuda, S. Kondo, M. Hanatani, H. Suzuki, and K. Yamashita. 1996. Vascular endothelial growth factor is induced by longterm high glucose concentration and up-regulated by acute glucose deprivation in cultured bovine retinal pigmented epithelial cells. Biochem. Biophys. Res.
Commun. 221:193-198.

53. Inabe,T., S. Ishibashi, T. Gotoda, M. Kawamura, N. Morino, Y. Nojima, M. Kawakami, Y. Yazaki, and N. Yamada. 1996. Enhanced expression of platelet-derived growth factor- $\beta$ receptor by high glucose. Involvement of plateletderived growth factor in diabetic angiopathy. Diabetes. 45:507-512.

54. Shweiki, D., M. Neeman, A. Itin, and E. Keshet. 1995. Induction of vascular endothelial growth factor expression by hypoxia and by glucose deficiency in multicell spheroids: implications for tumor angiogenesis. Proc. Natl. Acad. Sci. USA. 92:768-772.

55. Corbett, J.A., R.G. Tilton, K. Chang, K.S. Hasan, Y. Ido, J.L. Wang, M.A. Sweetland, J.R. Lancaster, J.R. Williamson, and M.L. McDaniel. 1992 Aminoguanidine, a novel inhibitor of nitric oxide formation, prevents diabetic vascular dysfunction. Diabetes. 41:552-556.

56. Xu, X.-P., J.S. Pollock, M.A. Tanner, and P.R. Myers. 1995. Hypoxia activates nitric oxide synthase and stimulates nitric oxide production in porcine coronary resistance arteriolar endothelial cells. Cardiovasc. Res. 30:841-847.

57. Arnet, U.A., A. McMillan, J.L. Dinerman, B. Ballermann, and C.J. Lowenstein. 1996. Regulation of endothelial nitric-oxide synthase during hypoxia. J. Biol. Chem. 271:15069-15073.

58. Wolff, D.J., and A. Lubeskie. 1995. Aminoguanidine is an isoformselective, mechanism-based inactivator of nitric oxide synthase. Arch. Biochem. Biophys. 316:290-301. 